\title{
PERANCANGAN APLIKASI GAME EDUKASI PENGENALAN KOMPUTER UNTUK ANAK DIDIK USIA SEKOLAH DASAR
}

\author{
Azil Fahrurozie \\ Program Studi Informatika, Universitas Indraprasta PGRI \\ azil.fahr@gmail.com
}

Submitted April 7, 2019; Revised June 22, 2019; Accepted July 20, 2019

\begin{abstract}
Abstrak
Penelitian ini dilatar belakangi oleh betapa pentingnya pembelajaran Komputer terhadap anak tingkat sekolah dasar, karena dengan pengenalan teknologi komputerisasi sejak dini maka anak akan terbiasa dengan teknologi komputerisasi dikemudian hari. Dari semua jenis media pembelajaran hiburan interaktif, media pembelajaran melalui game termasuk salah satu yang memiliki nilai lebih, karena pada dasarnya game adalah untuk hiburan dan dengan dijadikan media pembelajaran bisa membuat anak-anak atau para siswa menjadi lebih senang dalam belajar karena mereka bisa bermain sambil belajar dalam waktu yang bersamaan. Pembuatan game ini bertujuan untuk menambah wawasan bagi anak akan pentingnya teknologi, melalui game interaktif ini diharapkan user atau pengguna merasa tertarik dan tidak merasa bosan dalam belajar. Metode penelitian yang digunakan adalah Software Development Life Cycle (SDLC) Water Fall dan Game Design Document (GDD) yang menggunakan tahapan penelitian (1) tahap analisa, (2) tahap perancangan, (3) tahap pemrograman, (4) tahap pengujian, (5) tahap pemeliharaan. Tahap analisa kebutuhan mencangkup materi dan spesifikasi kebutuhan hardware dan software. Bentuk permainannya adalah sekitar pertanyaan mengenai seputar perangkat dan fungsi komputer dengan jawaban pilihan ganda. Seperti layaknya menjawab ujian, pemain tinggal mengklik salah satu jawaban dari setiap pertanyaan yang tampil dengan menggunakan game dengan aplikasi java.
\end{abstract}

Kata Kunci : Media, Game, Hiburan, Interaktif

\begin{abstract}
This event will be based on research by learning how important the Computer against the primary level, since with the introduction of computerized technology early on then the child will be familiar with computerized technology in the future.From all types of media, interactive entertainment media learning learning through games including one that has more value, because basically the game is for entertainment and with the Foundation of the learning media can make kids or students being more pleased in learning because they can play while learning at the same time.Making this game aims to add insight to children of the importance of technology, through this interactive game expected user or users feel interested and not feel bored in study.The research method used was the Software Development Life Cycle (SDLC) Water Fall and Game Design Document (GDD) who used the stage of the research (1) stage of analysis, (2) the stage of design, the programming phase (3), (4) the stage of testing, (5) stages maintenance.Needs analysis stage includes material and hardware and software requirements specifications. This form of the game is about questions concerning about the device and the computer functions with multiple choice answers.As well as answering the test, players stay clicking one answer to every question that appears by using the games with java applications.
\end{abstract}

Key Words : Media, Game, Entertaiment, Interactive

\section{PENDAHULUAN}

Game edukasi sangat menarik untuk dikembangkan. Ada beberapa kelebihan dari game edukasi dibandingkan dengan metode edukasi konvensional. Salah satu kelebihan utama game edukasi adalah pada visualisasi dari permasalahan nyata. Massachussets Institut of Technology (MIT) berhasil membuktikan bahwa game sangat berguna untuk meningkatkan logika 
dan pemahaman pemain terhadap suatu masalah melalui proyek game yang dinamai Stratch. Dari semua jenis media pembelajaran hiburan interaktif,media pembelajaran melalui game termasuk salah satu yang memiliki nilai lebih, karena pada dasarnya game adalah untuk hiburan dan dengan dijadikan media pembelajaran bisa membuat anak-anak atau para siswa menjadi lebih senang dalam belajar karena mereka bisa bermain sambil belajar dalam waktu yang bersamaan. Pembuatan game ini bertujuan untuk menambah wawasan bagi anak akan pentingnya teknologi, melalui game interaktif ini diharapkan user atau pengguna merasa tertarik dan tidak merasa bosan dalam belajar.

Game edukasi merupakan media alternatif untuk mengenalkan komputer kepada anak-anak karena game banyak disukai oleh anak-anak dan juga merupakan sebuah media pembelajaran yang efektif. Game Edukasi atau Permainan Pendidikan merupakan permainan yang dirancang khusus untuk mengajarkan pengguna tentang sesuatu hal [1].

Manfaat lain adalah aspek kecerdasan dan reflek saraf yang sebenarnya juga sedikit banyak terasah dalam sebuah game. Dengan belajar melalui visualisasi yang menarik. Diharapkan semangat untuk belajar tentang komputer lebih termotivasi. Karena selalu dimainkan berulang ulang dan terus menerus sampai para pemain game merasa puas, maka dengan sendirinya materi-materi yang disampaikan akan mudah dicerna dan dimengerti oleh pemain game. Beberapa Masalah yang peneliti temukan adalahcara belajar Konvensional kurang menarik minat anak-anak untuk belajar. Minimnya aplikasi-aplikasi menarik yang dapat menambah pengetahuan dan wawasan bagi anak dalam belajar komputer. Dalam penelitian [2] menjelaskan bahwa suasana belajar siswa bisa lebih menyenangkan dibandingan metode belajar yang lama.

Dalam penyusunan game terdapat beberapa elemen penyusun yaitu jenis game, karakter dalam game, background, elemen suara dan gerakan [2].

Pemograman Java turut berperan penting dalam perkembangan teknologi, ter masuk dalam perancangan aplikasi game[3]. Teknologi Java memiliki tiga komponen penting, yaitu: Programminglanguagespecification, Application programming interface, Virtual-machine specification[4].

Inti dalam pemrogramaan adalah game. Jenis atau tipe game yang dikembangkan dengan Java ini beragam ada yang berjenis mobile, desktop dan web base[3].

Berdasarkan latar belakang masalah yang telah diuraikan diatas, maka dapat dirumuskan sebagai berikut:

1) Bagaimana cara menarik minat anak untuk belajar mengenal komputer?

2) Bagaimana cara membuat aplikasi yang dapat menarik minat anak dalam belajar?

Tujuan dari penelitian ini yaitu :

1) Melalui pembuatan game ini, semangat anak didalam belajar akan meningkat serta pengetahuan mengenai perangkatperangkat dan fungsi komputer akan tersalurkan.

2) Membuat aplikasi hiburan sekaligus sebagai sarana pembelajaran, yang dapat digunakan oleh anak sekolah dasar.

3) Pembuatan game edukasi pengenalan komputer dibuat menggunakan bahasa pemrograman NetBeans.

\section{METODE PENELITIAN}

Penelitian ini dilakukan dengan metode Software Development Life Cycle (SDLC) Water Falldan Game Design Document (GDD). Metode Software Development Life Cycle (SDLC)Water Fall dimulai dari 
analisis, perancangan, pembuatan, pengujian dan pemeliharaan [5].

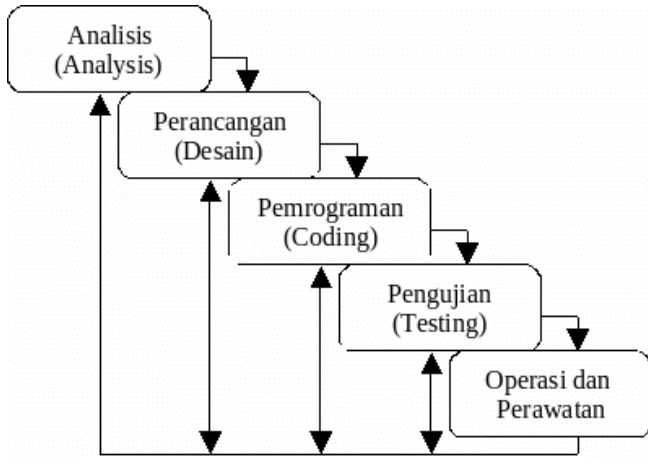

\section{Gambar 1. Metode Software Development Life Cycle (SDLC) Water Fall}

\section{Tahap Analisis}

Analisis pada Gambar 1, tahap tersebut dilakukan melalui observasi langsung kemasyarakat melalui penyebaran angket kuisioner mengenai tingkat pengenalan game edukasi dengan responden siswasiswa SD. Topik pertanyaan kuisioner yang disebarkan meliputi keterkaitan siswa terhadap game edukasi dan penguasan komputer dalam belajar.

\section{Tahap Perancangan}

Dalam tahap perancangan pada Gambar 1, perancangan game ditentukan melalui gameplay untuk tiap level permainan. Game edukasi ini berisi informasi mengenai perangkat-perangkat dasar komputer serta fungsi dasar dari perangkat tersebut yang dikemas dalam sebuah game.

\section{Tahap Pembuatan}

Tahap pembuatan pada Gambar 1, Pembuatan game edukasi pengenalan komputer diwujudkan dalam sebuah storyboard dari game.

\section{Tahap Pengujian}

Tahap pengujian pada Gambar 1, pengujian dalam game ini dilakukan melalui pengujian fungsionalitas sistem, pengujian game terhadap perangkat komputer dengan variasi RAM yang ditentukan, dan pengujian kemanfaatan game melalui kuisioner terhadap pengguna. Aspek yang dinilai melalui kuisioner yaitu tampilan aplikasi game dan aspek kemudahan informasi.

\section{Tahap Pemeliharaan}

Tahap pemeliharaan pada Gambar 1, pemeliharaan dilakukan melalui tahap release game edukasi pengenalan komputer versi 1 .

Game Design Document (GDD) atau sering disebut dengan rancangan game merupakan rancangan awal untuk membentuk sebuah game. Rancangan game ini biasanya dipakai pada industry game untuk mengelola pengembangan sebuah game. Rancangan game (GDD) terbagi dalam beberapa tahap, diantaranya adalah pembangunan sistem pada game. Pembangunan Sistem Proses pembangunan game ini dilakukan melalui beberapa tahap yaitu penentuan penggunaan perangkat, pembuatan desain game, scripting, serta proses pengujian.

1. Penentuan penggunaan perangkat merupakan proses menentukan perangkat apa saja yang akan digunakan dalam pembangunan sistem. Penentuan perangkat didasarkan pada hasil analisis kebutuhan sistem yang telah dilakukan sebelumnya. Perangkat lunak yang digunakan adalah : a. Sistem Operasi Windows 8.1 b. Corel Draw, untuk pemodelan dan pembuatan gambar. c. Fruity Loop, untuk mengolah suara latar dan suara efek. d.Unity, merupakan aplikasi akhir untuk membuat game. Perangkat keras yang digunakan adalah: Processor AMD RADEON E2-2000 APU 1,8Ghz; RAM 4 GB ; Kartu Grafis RAM 2037 MB ; Hard Disk 500 GB ; Layar monitor 1366 x 768 pixel ; Keyboard dan mouse ; serta Pentab.

2. Perancangan sistem game edukasi pengenalan komputer mengunakan sensor Accelerometer meliputi tiga tahap perancangan yaitu perancangan desain game, perancangan diagram HIPO dan perancangan antarmuka. 
Perancangan desain game merupakan gambaran umum game tersebut, serta scenario game. Perancangan desain game juga bertujuan untuk menjelaskan alur game sebelum masuk ke proses scripting dan juga meliputi gambaran dan rancangan umum dari game, serta skenario game.Perancangan diagram HIPO bertujuan untuk menunjukkan hubungan antara modul dengan fungsi pada game, serta memberikan gambaran dari struktur game. Proses ini dilakukan dalam proses pencarian informasi secara manual yang akan digunakan oleh user kemudian ditampilkan oleh sistem. Perancangan antarmuka bertujuan untuk memberikan kemudahan dalam mengimplementasikan perangkat lunak yang akan dibangun. Antar muka ini juga berfungsi sebagai sarana interaksi antara pemain dan game serta merupakan perancangan tampilan game yang meliputi perancangan karakter, bentuk dan komponen lainnya.

\section{HASIL DAN PEMBAHASAN}

\section{Hasil Perancangan}

Permainan pengenalan komputer ini adalah salah satu permainan yang dirancang untuk kebutuhan edukasi atau pengetahuan. Cara bermainnya pun samgat mudah dimainkan bagi semua kalangan. Bentuk permainannya adalah sekitar pertanyaan mengenai seputar perangkat dan fungsi komputer dengan jawaban pilihan ganda. Seperti layaknya menjawab ujian, pemain tinggal mengklik salah satu jawaban dari setiap pertanyaan yang tampil. Untuk setiap permainan harus menyelesaikan 5 tahap level permainan dengan tingkat kesulitan yang berbeda. Setelah menyelesaikan semua tahapan permainan, pemain akan mendapatkan score nilai dari hasil total jawaban yang benar.Adapun Struktur program sistem aplikasi permainan game edukatif pengenalan komputer ini dapat digambarkan menggunakan bagan untuk memudahkan dalam mempelajari sistem tentang program yang akan digunakan.

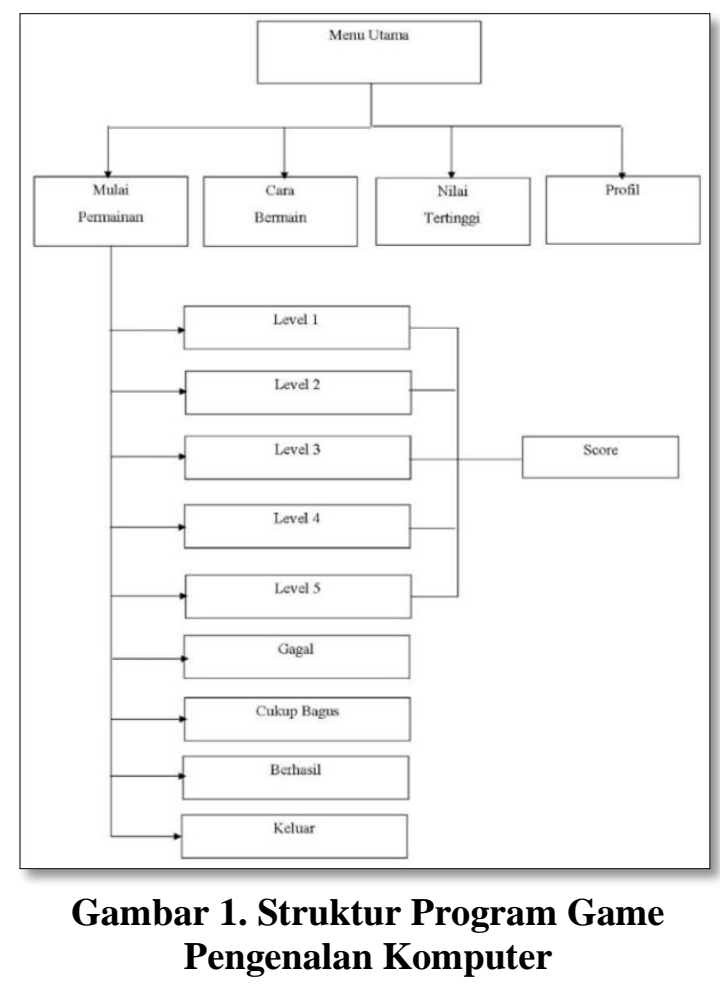

Flowchart yang dirancang pada game edukatif pengenalan komputer [6] dijelaskan pada gambar 2 .

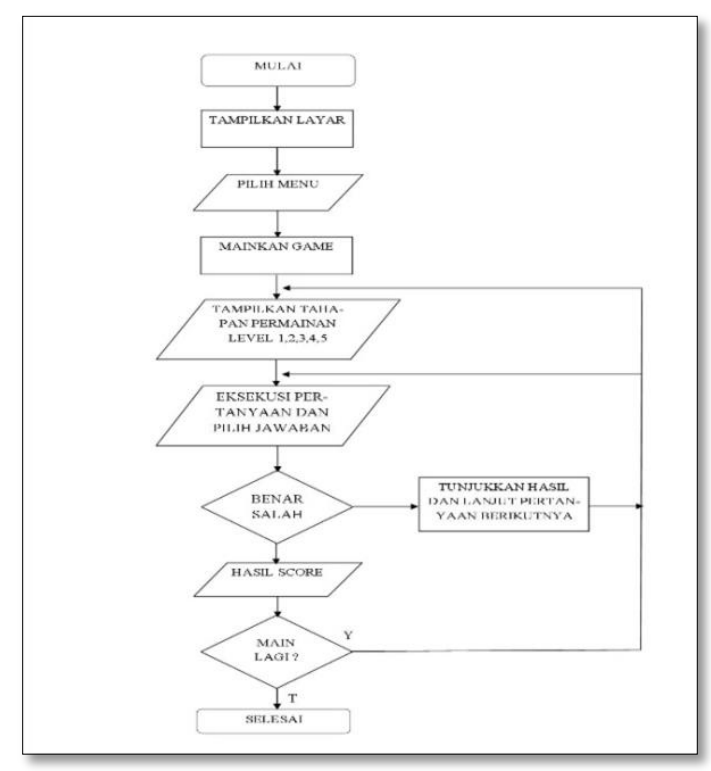

Gambar 2. Alur Program Game Edukatif Pengenalan Komputer 
Selanjutnya melalui alur program pada gambar 2 dipecah menjadi beberapa flowchart.

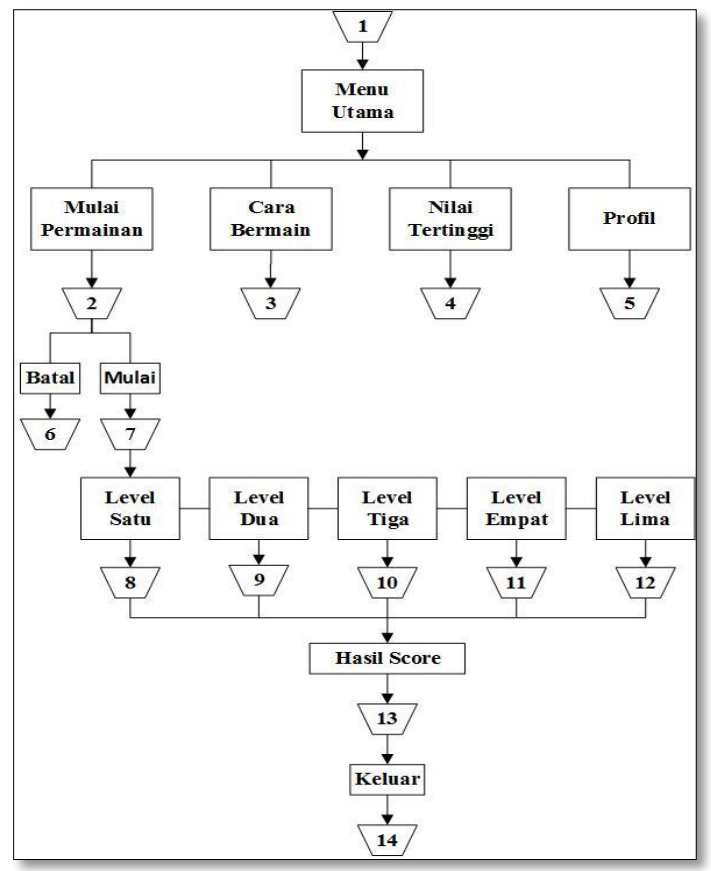

\section{Gambar 3. Flowchart Tampilan Utama} Aplikasi

Setelah tampilan Home Game klik button Mulai untuk masuk ke " Menu Utama ". Menu Utama terdiri dari 4 menu, lakukan;ah pilihan yaitu: Menu Mulai Permainan, Menu Cara Bermain, Menu Nilai Tertinggi dan Menu Profil pembuat. Semua menu akan menunjukan tampilannya masing-masing.

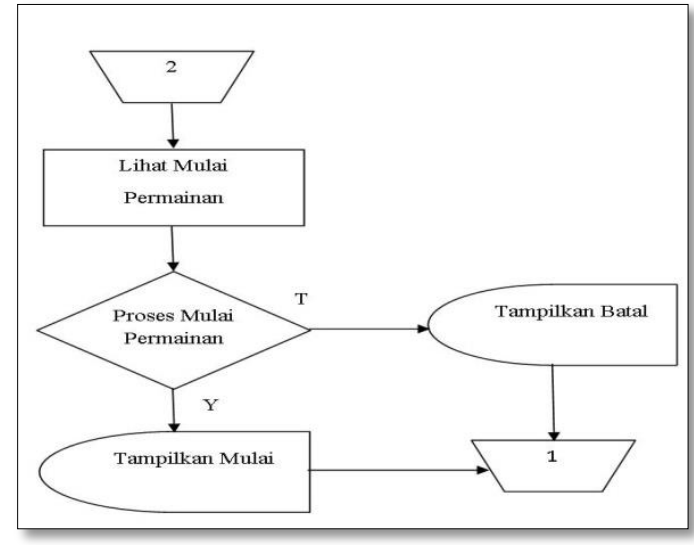

Gambar 4. Flowchart Mulai Permainan

Setelah masuk ke Menu Utama, pilih Menu "Mulai Permainan". Menu ini akan menampilkan menu baru yaitu Menu Mulai dan Menu Batal. Jika memilih Mulai maka akan menampilkan proses babak permainan, dan jika memilih Batal maka akan kembali ke Menu Utama.

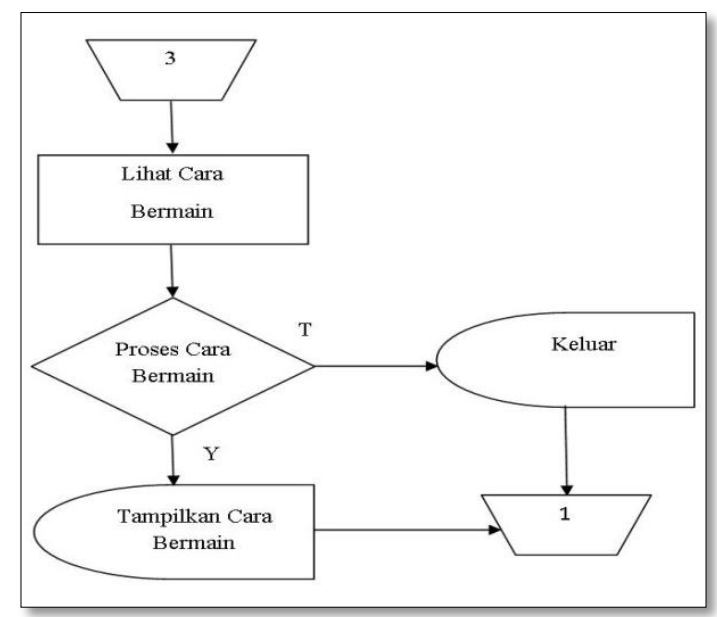

\section{Gambar 5. Flowchart Cara Bermain}

Setelah masuk Menu Utama pilih Menu "Cara Bermain". Menu ini akan menampilkan langkah-langkah Cara Bermain.

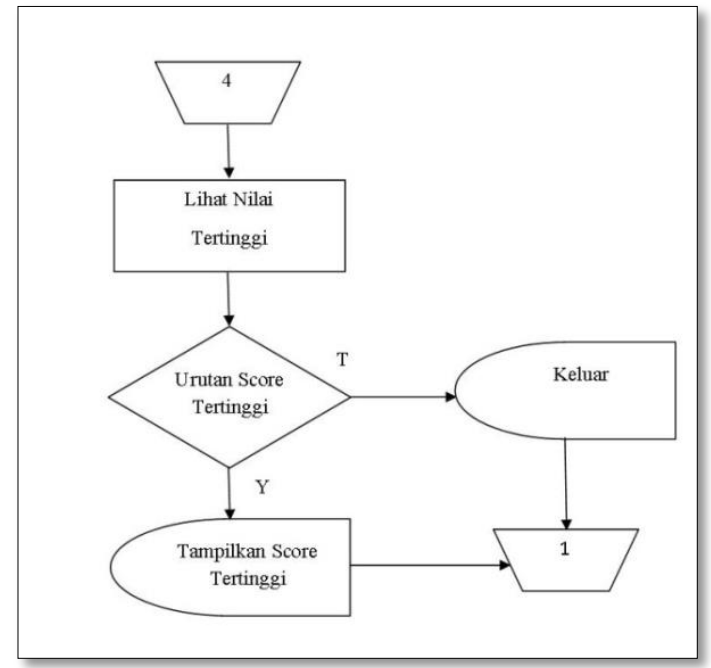

\section{Gambar 6. Flowchart Skor Tertinggi}

Setelah masuk Menu Utama, pilih menu “ Nilai Tertinggi ". Menu ini akan menampilkan urutan nilai score tertinggi dari permainan yang sudah dijalankan. 


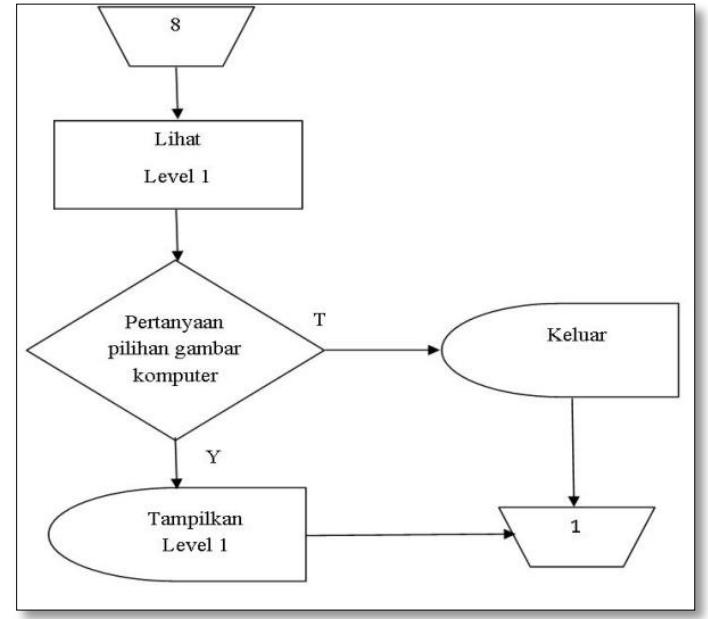

Gambar 7. Flowchart Level

Level dari game edukatif terdiri dari level 1 s.d 5.Setelah masuk ke menu Mulai, lakukan proses babak permainan " Level 1" dengan memilih salah satu jawaban pilihan ganda. Pada level ini akan menampilkan pertanyaan pilihan gambar komputer.

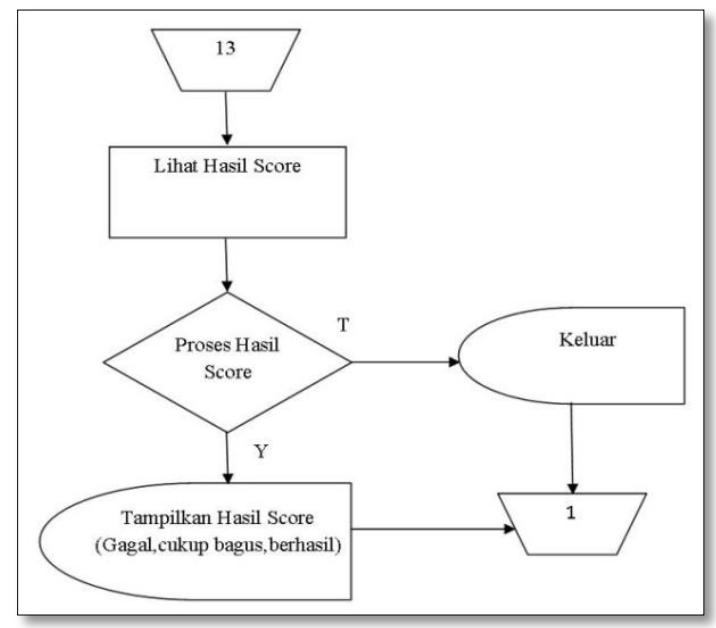

Gambar 8. Flowchart Hasil Skor

Setelah menyelesaikan permainan Level 5, maka akan ditampilkan "Hasil Score" dari hasil akhir permainan Level 1 sampai 5 [7].

Pada Menu Utama ini terdapat 4 (empat) menu pilihan yang masing-masing memiliki fungsi tersendiri. Data keluarannya (output) berupa informasi yang meliputi: a) Klik Menu Mulai Permainan yang berisi instruksi awal bermain dan didalamnya ada button Batal dan Mulai. Menu Batal untuk membatalkan permainan, sedang pada Menu Mulai untuk memulai permainan. Didalam Menu Mulai ada tahapan level 1, level 2, level 3, level 4, dan level 5 yang harus diselesaikan sampai akhir permainan untuk menghasilkan score/nilai.

b) Klik Menu Cara Bermain berisi keterangan cara permainan Game Edukatif Pengenalan Komputer Untuk Anak SD yang penulis buat.

c) Klik Menu Nilai Tertinggi berisi keterangan urutan hasil score dari yang paling tertinggi sampai terendah.

d) Klik Menu Profil berisi keterangan nama, npm, dan foto penulis.

Pada tahap ini juga, peneliti memulai persiapan pembuatan aplikasi yang terdiri atas beberapa langkah yang akan dijelaskan. Proses desain menu utama ini, dimulai dengan pembuatan Struktur Navigasi, yang kemudian dilanjutkan dengan pembuatan storyboard. Storyboard berfungsi untuk menggambarkan semua elemen yang akan tampak pada layar monitor, yang meliputi berupa letak teks, letak tombol, latar belakang yang dipakai, dan sebagainya.

Uji coba permainan pada perangkat nyata yaitu laptop yang telah didukung teknologi Java. Untuk dapat melakukan uji coba dari permainan ini diperlukan perangkat lunak pendukung yang akan menjadi media untuk menjalankan sistem yaitu sebagai berikut:

1) Windows 7 (seven) sebagai sistem operasi yang dipakai oleh penulis.

2) Netbeans IDE 8.0.2 sebagai Software yang penulis gunakan dalam membangun game edukatif pengenalan komputer ini. 
3) MySQL, sebagai pengembang basis data dan perangkat lunak lainnya menggunakan XAMPP

Implementasi Rancangan Layar

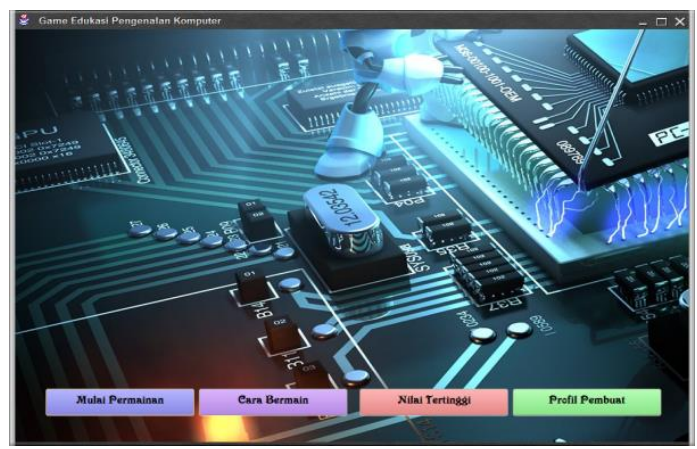

Gambar 9. Tampilan Awal Program

Gambar 9 adalah tampilan Home game, Lakukan klik "Mulai permainan" untuk masuk ke menu login atau daftar [8].

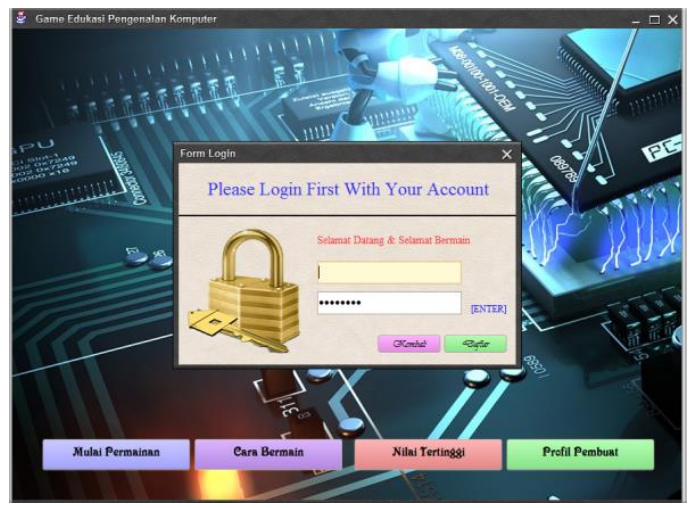

Gambar 10. Tampilan Login \& Daftar

Kemudian lakukan login dengan nama dan password yang sudah di miliki atau tekan tombol daftar untuk mambuat account.

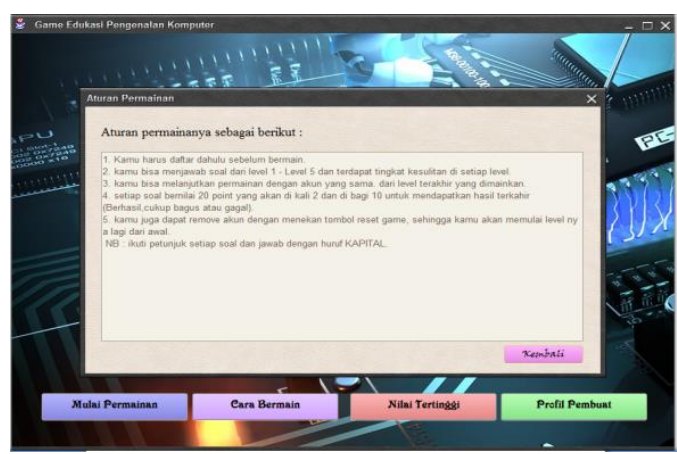

Gambar 11. Tampilan Cara Bermain

Untuk menjalankan permainan, lakukan klik "Mulai Permainan", maka akan muncul menu baru pada gambar 12 .

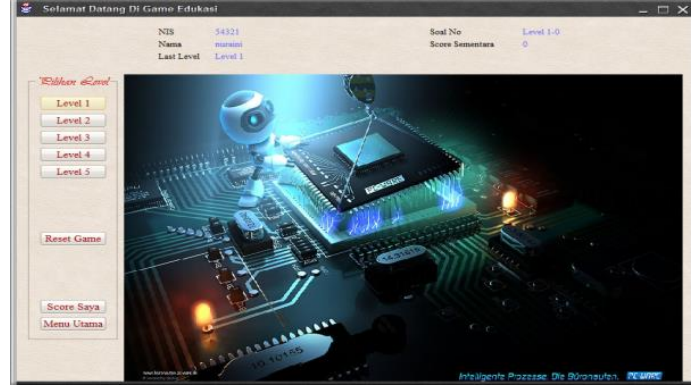

Gambar 12. Tampilan Level 1

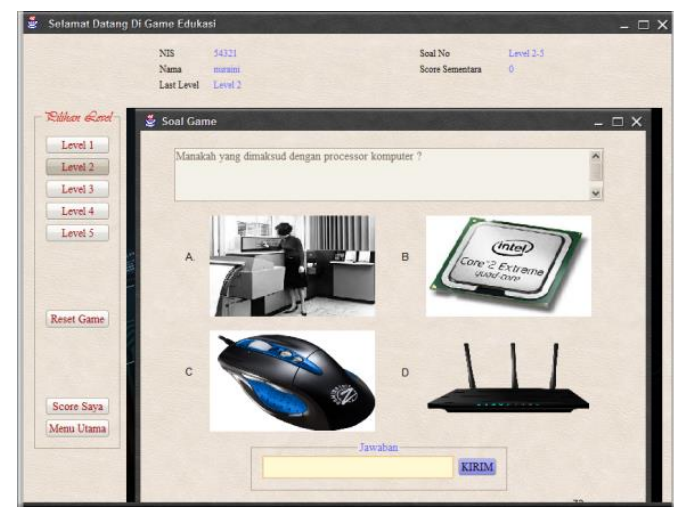

Gambar 13. Tampilan Level 2

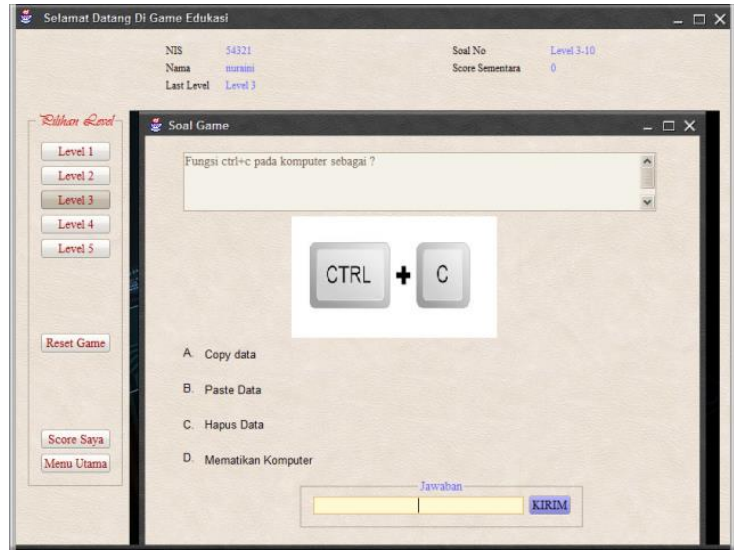

Gambar 14. Tampilan Level 3

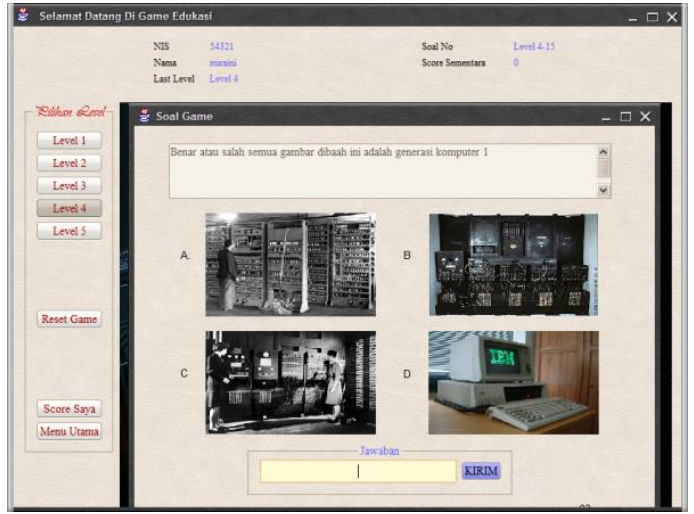

Gambar 15. Tampilan Level 4 


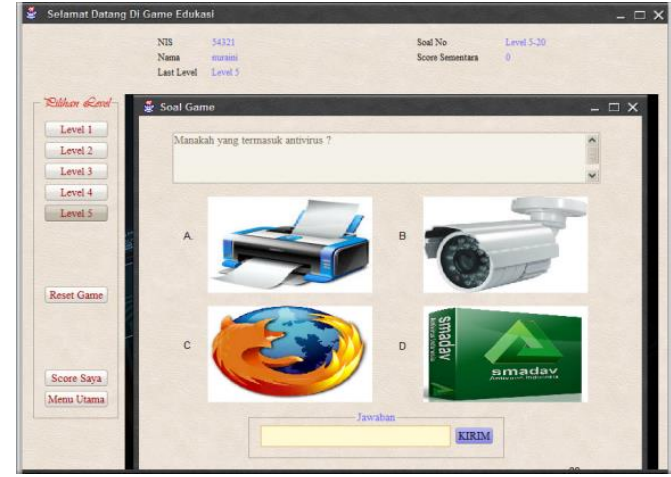

Gambar 16. Tampilan Level 5

Jika jawaban anda benar atau salah, akan muncul pemberitahuan

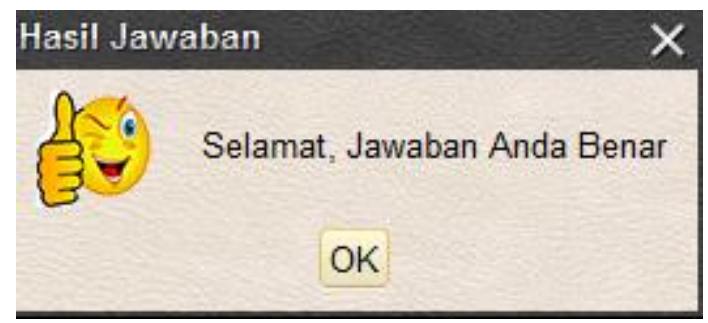

Gambar 17. Tampilan Jika Jawaban Benar

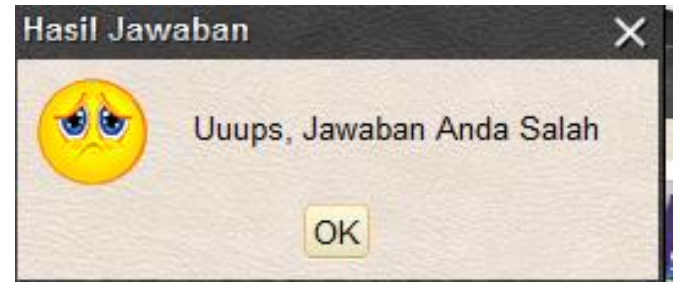

Gambar 18. Tampilan Jika Jawaban Salah

Setelah menyelesaikan semua tahapan level permainan, anda akan mendapatkan nilai score, jika hasil score anda "Kurang memuaskan", maka akan muncul tampilan seperti gambar 19.

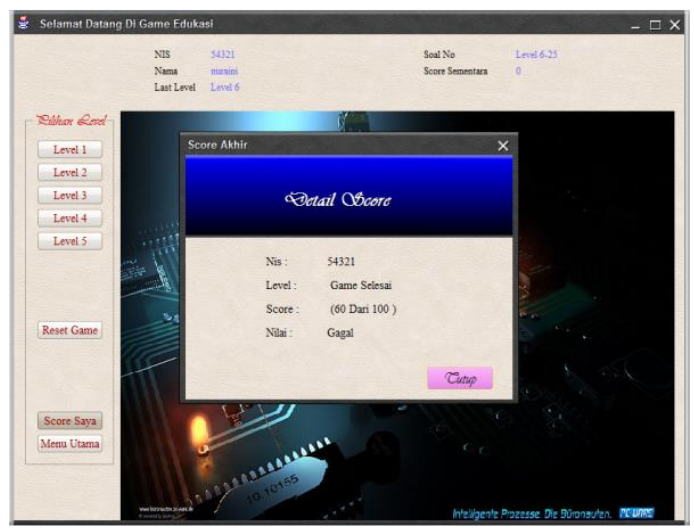

Gambar 19. Tampilan Skor Gagal
Jika hasil memuaskan maka akan muncul seperti tampilan pada gambar 20 .

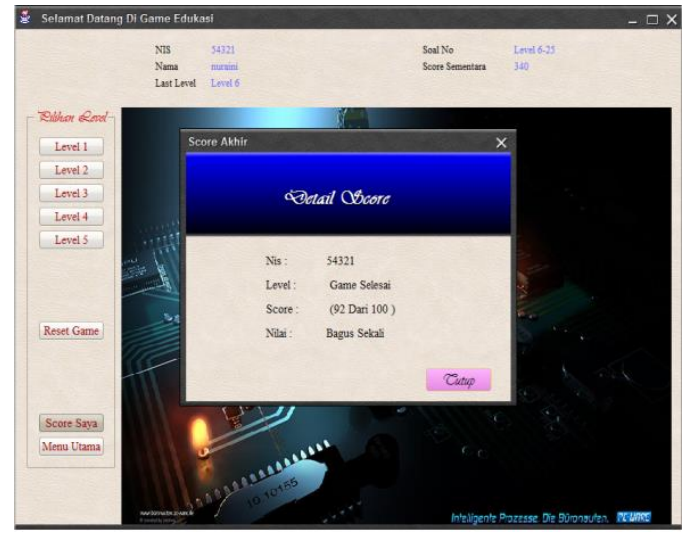

Gambar 20. Tampilan Skor Memuaskan

\section{Pengujian dengan kuesioner}

Pengujian dengan kuesioner Kuesioner siswa diberikan pada kelas 1 dengan jumlah 25 siswa, hasil pengisian dari kuesioner dari 7 kriteria penilaian pada 25 lembar kuesioner yang diberikan pada siswa ditunjukkan pada Tabel 1. Kuesioner berikutnya diberikan pada kelas 2 dengan jumlah 25 siswa, hasil pengisian dari kuesioner dari 7 kriteria penilaian pada 25 lembar kuesioner yang diberikan pada siswa ditunjukkan pada Tabel 2 [9].

Tabel 1. Hasil Pengisian Kuesioner pada Kelas 1

\begin{tabular}{cccccc}
\hline \multirow{2}{*}{ Kelas 1 } & \multicolumn{5}{c}{ Kategori } \\
\cline { 2 - 6 } & SS & S & C & TS & STS \\
\hline Responden & 150 & 22 & 3 & 0 & 0 \\
\hline
\end{tabular}

Tabel 2. Hasil Pengisian Kuesioner pada Kelas 2

\begin{tabular}{cccccc}
\hline \multirow{2}{*}{ Kelas 2 } & \multicolumn{5}{c}{ Kategori } \\
\cline { 2 - 6 } & SS & S & C & TS & STS \\
\hline Responden & 145 & 25 & 5 & 0 & 0 \\
\hline
\end{tabular}

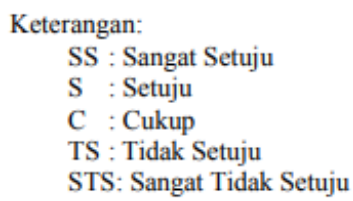

Perhitungan persentase akurasi

Skorl $=(150 \times 5)+(22 \times 4)+(3 \times 3)+(0 \times 2)+(0 \times 1)$

Skorl $=(750)+(88)+(9)$

Skorl $=847$ 


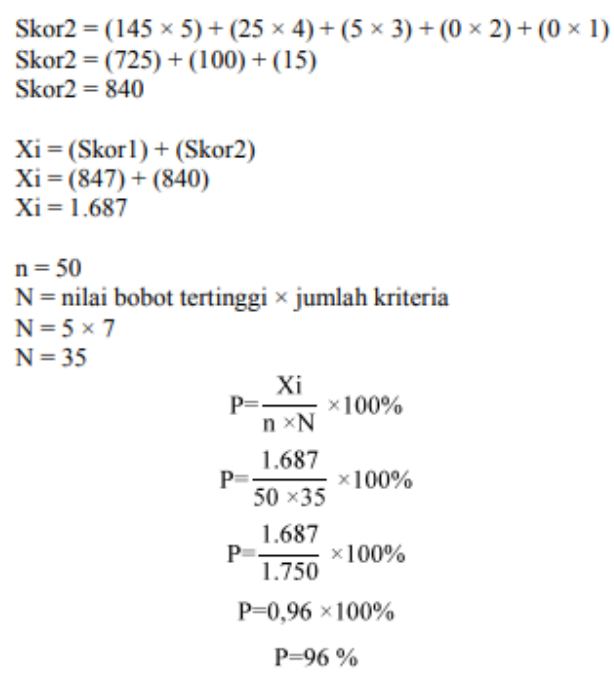

Dari hasil data pengujian kuesioner siswa, bahwa aplikasi game yang dibangun termasuk ke dalam kategori "Sangat Baik" dengan Hasil rata-rata yang diperoleh adalah 96\%. Hasil analisis pengujian dan pengisian kuesioner yang dilakukan terhadap siswa, total skor kategori tertinggi pada kuesioner yang dibagikan ketiga kelas adalah 295 dan total skor untuk kategori terendah adalah 8 . Kemudahan dan minat atau ketertarikan pada game oleh masingmasing siswa menjadi faktor utama tinggi rendahnya dalam menentukan penilaian terhadap game tersebut.

\section{Pembahasan}

1) Kelebihan Sistem

a. Sistem Aplikasi ini merupakan perangkat lunak yang dibangun dengan tujuan game ini dapat diimplementasikan pada PC atau Laptop yang didukung oleh teknologi Java[10].

b. Permainan ini banyak manfaatnya. Salah satunya adalah sebagai media pembelajaran pendidikan bagi siswa dan pengetahuan bagi khalayak umum.

c. Permainan ini bisa memerlukan daya ingat yang lebih agar dapat menyelesaikan atau memenangkan permainan ini. Semoga aplikasi yang dibuat oleh penulis dapat bermanfaat bagi para pembacanya. d. berdasarkan hasil pengujian kuesioner siswa, bahwa aplikasi game yang dibangun termasuk ke dalam kategori "Sangat Baik" dengan hasil rata-rata yang diperoleh adalah $96 \%$.

2) Kelemahan Sistem

Beberapa hal yang menurut penulis masih lemah dan kurang pada Aplikasi Game ini yaitu:

a. Tampilan masih belum optimal.

b. Jumlah soal yang kurang banyak.

c. Untuk sistem penggunaanya baru dapat digunakan pada perangkat PC atau Laptop saja.

\section{SIMPULAN}

Berdasarkan hasil dari perancangan aplikasi Game Edukatif Pengenalan Komputer Untuk SD Berbasis Java disimpulkan bahwa Pembuatan game ini dimulai melalui tahap pengumpulan bermacam-macam gambar perangkat komputer dengan kualitas gambar beresolusi tinggi. Kemudian dilanjutkan pencarian data untuk fungsi-fungsi dasar komputer. Perancangan sistemnya dengan membuat sketsa design tampilan dan mempersiapkan software-software pendukung untuk pembuatan aplikasi. Game ini merupakan sarana media pembelajaran mengenai pengetahuan dasar untuk pengenalan komputer , yang terutama ditujukan untuk para siswa sekolah dasar sebagai bekal dan persiapan ke jenjang pendidikan yang lebih tinggi. Untuk mendukung kelancaran dan kelestarian game maka penulis menyarankan beberapa hal yaitu:

1) Peningkatan metode permainan untuk memotivasi user/para pemain game dalam upaya pengenalan perangkat komputer terhadap siswa sekolah dasar.

2) Mengoptimalkan manfaat dari penggunaan PC dan Laptop sebagai sarana pembuatan aplikasi dan media pembelajaran. 
Game ini bertujuan tidak hanya sebagai hiburan semata, tetapi juga dapat meningkatkan pengetahuan dan wawasan siswa terhadap piranti dan fungsi komputer sebagai pengetahuan dasar dan bekal bagi siswa di jenjang pendidikan berikutnya.

\section{DAFTAR PUSTAKA}

[1] C. Agustina and T. Wahyudi, "Aplikasi Game Pendidikan Berbasis Android Untuk Memperkenalkan Pakaian Adat Indonesia," IJSE - Indones. J. Softw. Eng., vol. 1, no. 1, pp. 1-8, 2015.

[2] Y. Siswanto and B. E. Purnama, "Rancang Bangun Aplikasi Mobile Game Edukasi Ilmu Pengetahuan Alam Untuk Anak Kelas VI Sekolah Dasar," J. SPEED, vol. 5, no. 4, pp. 32-37, 2013.

[3] K. T. Martono, "Perancangan Game Edukasi ' Fish Identity' Dengan Menggunakan Java TM," J. Sist. Komput., vol. 1, no. 1, pp. 49-54, 2011.

[4] Busran and Fitriyah, "PERANCANGAN PERMAINAN ( GAME ) EDUKASI BELAJAR MEMBACA PADA ANAK PRASEKOLAH BERBASIS SMARTPHONE ANDROID ( Studi Kasus: Taman Kanak-Kanak Ikal Iqra Padang Selatan )," Teknoif, vol. 3, no. 1, 2015.
[5] Purnomo, F.A., Pratisto, E.H., NH, Taufiqurrakhman., Sahrul, F., Lestari, I.P. Pembuatan Game Edukasi Petualangan Si Gembul Sebagai Pembelajaran Pengenalan Daerah Solo Raya Pada Anak. Simetris. 17, 3-4. 2016.

[6] Lestari, U., Iswahyudi, C. Aplikasi Mobile Game Edukasi Matematika Berbasis Android. ResearchGate. 317184519, 5. 2013.

[7] Arifin, Z., Listyorini, T., Fiati R. Membangun Game Petualangan Sejarah Peninggalan Sunan Kudus Berbasis Android. Snatif. 2, 3. 2015.

[8] David. Perancangan Game Android Bergenre Horror. Cogito Smart Jurnal. 2, 7-8. 2016.

[9] Diakses dari Institut Teknologi Bandung uth website: https://blogs.itb.ac.id/indonesia/201 8/03/20/game-androidmenggunakan-emulator-yangringan/

(Diakses 17 Maret 2019)

[10] Diakses dari Institut Teknologi Bandung uth website: https://blogs.itb.ac.id/index/gameular-tangga-paling-seru-di-android/ (Diakses 19 Maret 2019) 